\title{
INATUALIDADE DE DIONÍSIO
}

Furio Jesi

1. Sobre o portal do templo de Vênus, imaginado por Angelo Poliziano, encontram-se, nas Estâncias, duas fileiras de baixos-relevos esculpidos por Vulcano; na primeira fileira são celebrados os eventos que precederam e acompanharam a epifania primordial de Vênus; na segunda aparecem dez exemplos míticos da potência da deusa. O grupo, composto pelos sexto, sétimo e oitavo relevos, representa Ariadne abandonada e a chegada de Dionísio com seu cortejo.

Esse tema não é único no Quatrocentos florentino. A Canzona di Bacco, composta por Magnifico Lorenzo, escande o encontro triunfal de Ariadne com o cortejo dionisíaco; um entalhe baseado em um desenho de Botticelli e um medalhão no pátio do Palácio Medici, modelado sob o exemplo de uma antiga gema, dele são os equivalentes iconográficos. Na evocação de Poliziano, o encontro entre Dionísio e Ariadne é acompanhado de outras imagens míticas nas quais a potência de Vênus se manifesta suscitadora de violência, seja quando um deus (Júpiter, Netuno, Saturno, Apolo) aparece com o semblante metamórfico ou no ato de sua ânsia amorosa, seja quando - no relevo ao lado desses dionisíacos - figura o protótipo da copulação como rapto: o rapto de Proserpina. Em toda a decoração do portal - que principia com a imagem, de primordial e cômica violência, da castração de Urano - só as figuras de Ariadne e de Dionísio exemplificam a potência de Vênus em forma não apenas serena, mas anunciadora de perenes serenidades futuras e de vitórias não revogáveis. As próprias imagens de Júpiter como cisne ou chuva de ouro - as aparências assumidas pelo deus para unir-se a Leda e a Dânae - aludem a copulações quase furtivas, a epifanias do amante divino circunscritas pelo "uma vez por todas" em vez de abertas ao futuro pelo "agora e para sempre".

Inattualità di Dionisio.

In: Materiali mitologici. Mito e antropologia nella cultura mitteleuropea.

Org. Andrea Cavalletti. Torino: Einaudi, 2001, p. 121-140.

Tradução de Vinícius Nicastro Honesko. 
É possível objetar que o tempo do mito é imóvel e que, portanto, na esfera do mito um instante vale a eternidade. Mas mesmo se o tempo do mito é efetivamente imóvel, existe na percepção que dele se tem uma constante que definimos "comprimento" em vez de "duração": comprimento todo simultaneamente percebido, assim como é percebida cada fração sua, de forma a fazer coincidir com o instante de quem percebe seja toda a realidade do tempo mítico seja as parcelas deste. A realidade essencial de tal duração é intrínseca não apenas à estrutura de um mitologema enquanto narrativa de eventos, mas também ao mais íntimo valor de revelação assumido por ele. Antes, seria preciso dizer que esse comprimento torna-se real quanto mais um mitologema adquire, em um determinado contexto religioso, valor de revelação e de redenção. Nesse sentido, no âmbito do mito, o "uma vez por todas" leva o homem para mais próximo de deus, enquanto o "agora e para sempre" aproxima o deus do homem.

Aqui jaz a raiz do valor triunfal e alegre do encontro de Ariadne com Dionísio. As núpcias de Ariadne e Dionísio cobrem todo o comprimento do tempo do mito, uma vez que Ariadne será a perene esposa do deus; o confronto, a cópula de Zeus com Dânae, corresponde a uma só fração do tempo mítico e é mais epifania de força do que revelação de socorro e de resgate. Entre Mabuse e Correggio, as figurações do Renascimento do ouro no ventre de Dânae por um lado deixam espaço ao alegorismo emblemático e, por outro, à pura realidade epifânica do mito, a qual envolve em tipos afrodisíacos o semblante da amante de Zeus. Mas no encontro de Ariadne com Dionísio o Magnifico Lorenzo vê não tanto um emblema e um simulacro, intimamente "repousantes em si mesmos", como escreve Bachofen, quanto um exemplo aberto ao futuro (e o futuro do mito é o homem), não apenas um emblema de verdade, mas um explícito símbolo de redenção:

Estes são Baco e Ariadne, Belos, e um pelo outro ardentes:

Porque o tempo foge e engana,

Sempre juntos estão contentes.

A antítese entre o terceiro e o quarto versos é reveladora. Ao tempo que "foge" e "engana" - portanto, ao tempo humano - , contrapõe-se o "sempre" do mito salvador.

No canto carnavalesco, todavia, não se poderia encontrar - nem mesmo 
como memória de dor já derrotada pela epifania do deus - o patetismo de Ariadne abandonada, destinado a assinalar, cento e trinta anos mais tarde, o madrigal de Claudio Monteverdi e isso para conferir aparência de socorro à aparição dionisíaca. O casal mítico é redentor porque sua realidade reside na simultânea epifania de Afrodite e de Dionísio. Seria errado não distinguir os diversos planos em que se configurou o mitologema como em um relevo paisagístico do helenismo: o precedente da dor e do sono de Ariadne é assim no âmbito interno do mito, o qual volta ao exterior apenas o rosto do triunfo e da alegria, a máscara divina de Dionísio. Justamente nessa duplicidade da imagem do deus - dor voltada ao interior, felicidade triunfal para o exterior reside o paradoxo dionisíaco: o sofrimento que é o outro rosto da salvação não na sorte do devoto, artificialmente coligada aos eventos iniciáticos, mas na efígie do deus, efígie de fato dupla, bifronte.

O primeiro modelo de Lorenzo foi, com toda probabilidade, a Arte de amar, de Ovídio. Mas uma versão muito mais antiga do mito afirmava que Ariadne, quando Dionísio a encontrou na ilha Dia, não jazia entregue ao sono, mas estava morta. E Igino, acolhendo uma tradição secular, narrava que Dionísio já havia esposado Ariadne em Creta, dando-lhe a coroa de ouro com a qual ela depois fez a luz para Teseu no labirinto: Ariadne teria sido morta por Ártemis, a pedido de Dionísio, pois se mostrara infiel e concedera a Teseu a coroa nupcial recebida pelo deus. No instante que precedia a aparição de Dionísio na ilha, Ariadne morria, uma vez que havia sido culpada. Extrair desse mito um precedente do destino da alma, redimida pelo deus e tornada imortal, significaria alterar injustificadamente, ou como - de maneira justificada desde seu ponto de vista - poderiam ter feito os apologistas cristãos, as relações antigas entre mito e homem. Isso porque o mito jamais é alegoria, emblema, destino do humano, mas genuíno precedente deste: precedente, realidade diferente por excelência já que precede a realidade humana. Nada nos consente crer que os devotos de Dionísio identificassem a sorte da sua "alma" com a de Ariadne, culpada, morta, e então ressurgida e glorificada por obra do deus. Podemos sustentar, ao contrário, que a primeira parte dolorosa e culpada dos eventos de Ariadne coincidisse com um aspecto da efígie de Dionísio - o obscuro - , enquanto o triunfo do casal deveria corresponder à epifania do outro aspecto - o luminoso. A cisão entre Ariadne e Dionísio, no primeiro momento (no qual, além disso, correspondem os sofrimentos que se abateram sobre o deus segundo a tradição órfica, ou seu aprofundamento no pân- 
tano de Lerna por obra de Perseu), corresponde, aliás, à inteireza do casal no segundo momento - luminoso. Na gênese dessa contraposição intervieram provavelmente as relações antigas entre Dionísio e a divindade feminina, depois sobrevivente em Ariadne, determinantes de uma sujeição e, talvez, também de um sacrifício para os quais seria oportuno invocar o testemunho de Bachofen sobre a soberania das grandes deusas. O hermafroditismo de Dionísio está enraizado nessa esfera e é significativo que ele tenha sobrevivido (mesmo que nas figuras em aparência desdobradas do casal) apenas no instante luminoso e triunfal. É possível entender, com efeito, o triunfo dionisíaco das núpcias com Ariadne como reconquistada inteireza, depois da longa sucessão (também em termos históricos) da fratura da andrógina. Mas também desse ponto de vista seria superficial entender a sorte do deus como paradigma daquela dos devotos, uma vez que a relação entre um deus e seus devotos, se mediada pelo mito, não pode ser de imitação (como, por outro lado, será no cristianismo), mas, sim, permanece sempre no limite do abismo entre divindade e homem; e a epifania mítica, como ponte sobre tal abismo, jamais é um socorro enquanto fonte de analogias salvadoras, mas, antes, é como revelação de categorias dos seres (humano) que, mesmo não tendo nada a ver com os deuses, são sujeitos aos deuses. Assim, o hermafroditismo de Dionísio é, antes de tudo, "coisa que diz respeito a Dionísio", não aos seus devotos: estes contemplam a efígie do deus e podem mais ou menos corretamente articular com o ritual categorias do ser humano: nem imitar, muito menos procurar identificar-se com a divindade. O travestismo, os símbolos andróginos do ritual, a orgia, são aparatos cultuais: "coisas dos deuses" que os homens tomam em mãos, não "coisas dos homens".

Dionísio ainda estava presente quando Lorenzo de' Medici quis “variar não apenas o canto, mas as invenções e o modo de compor as palavras" das canções de baile cantadas durante o carnaval por aqueles que amavam, "mascarando-se, contrafazendo as madonas usuais e andando pelas festas de maio". Mas justo pela forma aparentemente profana é que tais canções de baile, cantadas com "rituais" de tão antiga tradição, podiam consentir a epifania vitoriosa de Ariadne e de Dionísio. A profanação alegre era a extrema confirmação da diversidade entre deus e homem e das forças redentoras do deus. Parece, por outro lado, que as formas da loucura conservaram uma secreta coerência com o "sagrado discurso" no ponto em que constringiram Nietzsche a identificar-se com o deus e a escrever a Cosima Wagner "Ariadne, te amo", quando o 
destino pessoal de Nietzsche, no seu curso, por certo irrefreavelmente lançado a uma meta, obriga-o a refutar a redenção de Dionísio e a tornar-se cada vez mais "carrasco de si mesmo" reconhecendo em si o deus.

2. Reconhecer no dionisíaco uma constante da experiência humana (ou, caso se queira, em particular um conteúdo perene de determinadas formas de consciência) é tentação em que várias vezes se caiu na história da cultura europeia. A primeira crítica ao ponto de vista que leva a ceder a tal tentação consiste na precária aplicabilidade de um esquema temporal (justamente, a constante) a uma realidade que se subtrai a priori à dimensão temporal apreciada pelo historicismo. Falar de uma "constante fora do tempo", ou de uma "perenidade atemporal", significa recorrer a paradoxos aceitáveis apenas se para além deles aflora a noção de uma dupla realidade, pela qual valeria o "até aqui somos nós" e o "o resto é coisa dos deuses", utilizado por Rilke nas Elegias de Duíno.

Henri Jeanmaire, em todo seu volume ${ }^{1}$, geralmente foge do paradoxo da "perenidade atemporal" usufruindo de técnicas não dissimilares daquelas das pesquisas naturalísticas, isto é, isolando entre os testemunhos do fenômeno antigo algumas relações mecânicas repetíveis e repetidas em contextos cronologicamente mais próximos (ou, até mesmo, contemporâneos a nós). A presumida continuidade se transforma assim em uma latente repetibilidade, ao menos referida a singulares seções do fenômeno, e a essência do próprio fenômeno permanece ancorada nos mecanismos (ou, talvez, no "sentido") de um determinado e não repetível instante da história. Daí a observação conclusiva de Jeanmaire, que pode soar desconcertante, sobre a "inatualidade" de Dionísio.

É provável que Jeanmaire tenha razão: Dionísio não é "atual" e apenas com arbítrio se pode reconhecer na religião dionisíaca historicamente configurada um "dionisismo" perene. Isso não significa, entretanto, que Dionísio, como "deus da dor", não tenha gozado de uma fortuna secular, em muito posterior ao limite histórico da devoção organizada para ele. E sobretudo, isso não significa que tal fortuna do deus "inatual" fosse efetivamente inatual.

Do passado o que verdadeiramente importa é o que se esquece. O que se recorda é apenas sedimento e escória. O que importa, o que é destinado a

\footnotetext{
${ }^{1}$ JEANMAIRE, Henri. Dionisio. Religione e cultura in Grecia. Trad. Gustavo Glaesser. Torino: Einaudi, 1972.
} 
sobreviver, sobrevive aparentemente em segredo, na realidade, no modo mais óbvio, uma vez que sobrevive como matéria existente de quem experimentou o passado: como presente vivente, não como memória de passado morto. A experiência dionisíaca consentia, portanto, teologizar essas proposições. Dionísio era o deus da dor, uma vez que é dolorosa a perda do passado quando o passado não é lembrado enquanto permaneceu presente. A mecânica e superficial interpretação do esquema de morte e renascimento, entrevisto nos testemunhos da religiosidade dionisíaca, pode ser modificada neste sentido: assim como na iniciação primordial, a experiência de morte e renascimento é, antes de tudo, mudança, passagem de um estado a outro, de um tempo a outro. A morte que preludia o renascimento é o abandono do passado, o qual cessa de ser tal e não é lembrado uma vez que se tornou presente. $O$ renascimento é, portanto, a experiência daquele presente que compreende em si tudo o que do passado era vivo e é vivo: tudo o que não se recorda.

Esse é apenas um esquema temporal da dinâmica interna à experiência religiosa dionisíaca. Qual é o conteúdo dessa experiência? Paradoxalmente, teremos razão em afirmar que o conteúdo é o próprio esquema temporal, a passagem, a perda do passado enquanto tornado presente. Com justiça se reconheceu em Dionísio o deus da dor. O que por certo torna bifronte aos nossos olhos o rosto de Dionísio é a dor implícita no renascimento: a dor que é fatal no acesso à alegria. Mas nesse ponto se sobrepõe ao esquema temporal o esquema metafísico, ou, em outros termos, torna-se óbvio o sentido da medida temporal. A partir do momento em que o passado é o "até aqui somos nós" pronunciado pelos homens e o presente é o "o resto é coisa dos deuses". E quando na experiência dionisíaca o passado é esquecido, e assim tornado presente, o homem tem acesso ao "o resto é coisa dos deuses", experimentando a dor do estar distanciado do "até aqui somos nós".

Quando se fala de ebriedade dionisíaca e do erotismo orgiástico dionisíaco não é possível não levar em conta essa consagração do presente, que é, ao mesmo tempo, laceração e alegria, passagem: superação dos limites. A experiência erótica da orgia é, portanto, o mais cru e doloroso presente absoluto. Os símbolos sexuais da iconografia pré-histórica são, por outro lado, garantia de vida não tanto como garantia do perdurar da espécie quanto como emblemas, símbolos eficazes, do absoluto presente. A orgia é antes de tudo atualidade, simultaneidade (em termos de iconografia pré-histórica seria possível dizer: coexistência por transparência), presente. E a tradicional sentença la- 
tina "Post coitum animal triste" deve ser entendida não tanto no sentido de lamentação ou de percepção de culpa quanto no sentido de confirmada perda do passado. Todavia, alguém poderá objetar que, apesar de tudo, trata-se igualmente de percepção de culpa, uma vez que o passado perdido é talvez primordialmente inocência (o "Virgindade, virgindade te perco...", de Saffo).

A recorrente fortuna do "dionisismo" permite observar o paradoxo da dor implícita no renascimento em uma perspectiva mais ampla, de maneira a envolver não só o passado pessoal do indivíduo, mas também o passado de uma comunidade, de uma geração, de uma cultura. O "dionisismo" é, com efeito, inatual e assim o foi recorrentemente no curso das relações entre a cultura dos homens dos últimos cincos séculos e a antiguidade clássica, na medida em que a experiência religiosa dionisíaca foi esquecida e, desse modo, tornou-se matéria vivente dos indivíduos presentes. Do ponto de vista de um historiador e de um filólogo rigoroso como Jeanmaire, o "dionisismo" experimentado por Lorenzo de' Medici ou aquele experimentado por Nietzsche não eram o dionisismo originário, o qual teria sido profundamente inatual tanto no século XV quanto no XIX. Mas aquele dionisismo, o originário, era "o que do passado se esquece" e o "dionisismo" do Magnifico Lorenzo ou o de Nietzsche eram o presente nutrido pelo passado - o presente em que não se pode mais reconhecer o passado uma vez que este se tornou presente. Sem dúvidas, tanto Lorenzo quanto Nietzsche estavam convencidos de "recordar o passado": na realidade - e Jeanmaire o demonstra - , nem o recordavam nem teriam podido recordá-lo. Um e outro - não apenas eles, aliás - sofreram as penas de quem perdeu o passado; sofreram, mesmo se com frequência não souberam nisso reconhecer a causa (uma vez que acreditavam recordar-se do "passado"), mesmo se ao menos um deles - por certo Nietzsche - teve a propósito disso mais que uma repentina iluminação. Não por acaso, no parágrafo 224 de Além do bem e do mal [Jenseits von Gut und Böse], Nietzsche escreveu: "os nossos instintos percorrem todos caminhos do passado, nós próprios somos uma espécie de caos: - mas, por fim, como já dissemos, o 'espírito' sabe encontrar sua vantagem". Dir-se-ia, em uma primeira e superficial leitura, que "percorrer todos os caminhos do passado" seja exatamente o contrário do ter "perdido o passado". Mas, olhando-se mais a fundo, parece muito mais provável que o "percorrer todos os caminhos do passado", por parte dos "nossos instintos", significa ter esquecido o passado, uma vez que o que do passado é vivo é o presente. Mas não sem dor se é destacado do passado para possuir 
apenas o presente, não sem dor se renasce - não sem morrer.

3. A consciência dessa dor fatal - a noite em que o passado desaparece quando se torna presente - pode ser entendida como consequência do distanciar-se dos deuses: como, nas palavras de Hegel, o período da "consciência infeliz". A antítese entre noite e dia, que Hölderlin evocou como perene alternância na elegia Pão e vinho [Brot und Wein], pode coincidir (invertendo os termos contumazes das suas interpretações) com a alternância passado/ presente, no ponto em que a noite é o passado tornado presente e o dia é o presente no qual se esqueceu o passado (justo porque tornado presente). 0 dia é, desse modo, paradoxalmente a noite "sagrada" em que "des Weingotts heilige Priester, / ... von Lande zu Land zogen." ${ }^{2}$

Afirmar que "passado" no dionisismo originário coincida com a matéria mesma do devir e que "presente" seja nome do átimo em que o devir parece frear-se, pois conduzido ao seu paradigma (ou ao seu primeiro motor) no rosto do deus, significa retornar à coincidência heráclita dos opostos Hades/ Dionísio, e, portanto, prolongar a sequência passado/presente em invisível/ exibido. Louis Gernet, nas suas observações sobre o livro de Jeanmaire, com justiça apontou que uma característica fundamental da obra consiste em chamar a atenção para a "inapreensibilidade" da personalidade de Dionísio e para a escarça originalidade dos elementos cultuais e mitológicos que aí se ligam. Dionísio, como ilustra Jeanmaire, não pode ser individualizado recorrendo essencialmente às componentes específicas dos seus cultos e dos seus mitos (de cuja maior parte mostra-se herdeiro, para não dizer usurpador): sua autêntica originalidade, a verdade mais profunda da sua personalidade - entre as mais fortes e fascinantes do panteão helênico - reside e é concluída na sua própria presença. De modo diferente de quase todos os deuses gregos, ele não revela sua fisionomia nas atividades religiosas que preside ou nas tradições míticas de que é protagonista: elas se reagruparam em torno dele, quase como sobreposições a posteriori, por causa de alguns aspectos (e não sempre aspectos fundamentais) do universo próprio que ele impõe com sua presença única. Dionísio é, portanto, exibição de uma realidade cujo ser profundo é diferenciado pela tonalidade passado-morte-invisível: Dionísio é o paradoxo divino do recordar o que se esquece, do presente no qual o passado sobrevive

\footnotetext{
${ }^{2}$ Em alemão, no original. Tradução: "sacerdotes santos do deus do vinho / ... vagueavam de terra em terra." (n. t.)
} 
justo porque cessou de ser. Com muita exatidão Jeanmaire especifica que Dionísio não é o "deus da morte" e que não existe um seu "paraíso" como sede ultraterrena dos seus eleitos; Dionísio não é "deus da morte", mas com sua presença única evoca a morte e o além. Ao sublinhar essa tese de Jeanmaire, Gernet tocou um ponto fundamental da essência de Dionísio, configurando o deus dentro do contexto do pensamento de Platão como o provável Outro, o oposto ao mundo das ideias. Isso enriquece e aperfeiçoa o conceito de deus inapreensível, transformando-o naquele de deus da antítese, no quadro do fenômeno em que Gottfried Benn disse "o Nada que exorta à forma". Dionísio é "a exibição do nada": o passado que dura dentro do presente no instante em que cessa de ser.

O distanciar-se do passado, que cai no nada quando dura no presente, é a noite seguida do distanciar-se dos deuses? Se, como nós pensamos, a resposta deve ser afirmativa, a consequência do distanciar-se dos deuses - a noite da "consciência infeliz" - coincide não apenas com a dor fatal na fratura entre passado e presente, mas com a necessidade de morrer antes de renascer. $\mathrm{O}$ antigo pressuposto das experiências iniciáticas torna-se norma fundamental da experiência humana do ser, quando diante dos homens são colocados não os deuses identificáveis com base em suas prerrogativas e nos seus mitos, mas os deuses - como Dionísio - "inapreensíveis": os deuses que são exclusivamente "o divino", que não são suscetíveis de atributos reveladores, mas que com sua presença evocam a realidade do universo.

Nesse ponto é importante notar que o deus grego mais suscetível, além de Dionísio, de ser identificado como "o deus" por excelência, além de todo atributo e de toda prerrogativa cultual e mítica, é Apolo. É de fato impossível descrever Apolo como um determinado aspecto do divino; os próprios temas de sua mitologia são proposições das grandes constantes do ser no reflexo da sua presença. Não por acaso, portanto, aqueles que nos últimos duzentos anos experimentaram as dores da "consciência infeliz" com muita frequência se encontraram diante da antítese Dionísio/Apolo. Não pensemos apenas em Nietzsche, mas em Creuzer, em K.O. Müller, em Bachofen. Seria possível dizer, com efeito, que o drama ínsito nas relações com o passado "sagrado", o drama do dever esquecer para saber verdadeiramente, tenha assumido as formas de uma discórdia entre Dionísio e Apolo, porque eles - como "divindades por excelência" e não singulares aspectos do divino - podiam identificar-se melhor do que qualquer outro deus com os deuses "ausentes". Assim foram 
reconstruídas neles as duas fases, respectivamente de perda e de recuperação, que condicionavam as relações com o passado "sagrado" e que, tomadas de modo isolado uma da outra, não podiam conduzir à plenitude. "Die griechische Bildung ist ein Ganzes" ${ }^{3}$, afirmou Friedrich Schlegel, e tal sentença era destinada a valer não só como advertência para a filologia (a fim de que afrontasse a cultura helênica na sua globalidade), mas como reconhecimento da incindibilidade entre Dionísio e Apolo, não tanto na originária "realidade histórica" quanto nas faculdades cognoscíveis de quem jazia dentro da noite da "consciência infeliz". A insistência no caráter trágico e doloroso da experiência dionisíaca nasce então não apenas de uma tonalidade primordial da presença do deus, mas sobretudo da impossibilidade de isolar o universo que ele impõe daquele que impõe Apolo, e, portanto, da fatalidade de um contraste insanável. Aqueles que viviam na noite da "consciência infeliz" não se limitaram a voltar-se para os mitos antigos como a fontes de revelação, mas criaram uma nova mitologia: evocaram novas imagens de divindade no instante mesmo em que percebiam dolorosamente as consequências do afastar-se dos deuses. Os nomes de Apolo e de Dionísio, como aparecem nos escritos de Friedrich Schlegel, dos românticos de Heidelberg, de Bachofen ou de Nietzsche, designam duas novas divindades que correspondem às duas fases do doloroso esquecer/saber nos confrontos do passado; e tais nomes são fatalmente os nomes das duas divindades antigas em que o divino sofria menos limitações atributivas: Apolo e Dionísio, os "deuses por excelência”, os protótipos - enquanto tais - dos deuses que se distanciaram.

Isso não quer dizer, naturalmente, que a antítese Apolo/Dionísio não tenha algum significado originário na história da religião grega; mas é provável que no âmbito grego seria mais exato falar de uma diferença do que de uma antítese. Apolo foi profundamente diferente de Dionísio (basta pensar, por um lado, nos vínculos estreitíssimos entre a religião de Apolo e a política, e, por outro, na absoluta estraneidade de Dionísio em relação à esfera política), mas os dois universos impostos pela presença das duas divindades não deviam de fato ser evocados ao mesmo tempo, de modo a constantemente configurar o contraste. As páginas muito equilibradas que Jeanmaire dedica à presença seja de Apolo seja de Dionísio no santuário de Delfos esclarecem que Dionísio "não despertava o ciúme de Apolo, uma vez que não aparecia em

\footnotetext{
${ }^{3}$ Em alemão, no original. Tradução: "A educação grega é um todo." (n. t.)
} 
concorrência com Apolo no âmbito que este se reservava". Por certo não se tratava apenas de uma diferença formal entre o culto de Apolo, eminentemente oracular, e o de Dionísio, quase estranho à mântica (na Grécia), mas sim da fundamental autonomia das duas esferas, dos dois universos, evocadas por uma e outra divindade: autonomia que tornava precário o contraste, enquanto por vezes podia consentir (como em Delfos) a aliança. Mas justo essa autonomia entre a divindade que com sua presença única impunha o pensamento do além e a divindade depositária da interpretação da palavra do "divino" tornou-se impossível para quem vivia na noite da "consciência infeliz", depois que os deuses "se distanciaram". Nasceram então os dois novos rostos: Apolo e Dionísio como símbolos de um contraste perenemente ativo e insanável, que era sobretudo o contraste fundamental no acesso ao passado - o contraste entre viver e saber, entre abandono e razão, o paradoxal esquecer para saber que, em termos temporais, tornava-se o esquecer o passado para vivê-lo no presente. Se, entretanto, eliminamos da proposição precedente o adjetivo "paradoxal" (ou se, pelo menos, considerarmo-lo apenas como atributo da genuinidade do acesso ao divino), de novo nos encontraríamos no âmbito originário do antigo Dionísio. Toda a dialética entre Dionísio e Apolo se transforma de linguagem da nova mitologia do tempo da "consciência infeliz" em autêntica linguagem dionisíaca, se eliminarmos os nomes das duas divindades e reconhecermos em seu lugar duas constantes no interior do dionisismo. Como já dissemos, é de fato oportuna a definição da essência da experiência dionisíaca como lei "do Nada que exorta à forma”, definida por Benn. Mas não se trata de um contraste trágico e doloroso, mas sim, e de modo mais exato, de um paradoxo: na época em que os deuses "ainda não se distanciaram", o paradoxo do divino.

4. Não longe das experiências românticas da "consciência infeliz" está o ateísmo do marques de Sade; e sobretudo tal analogia tem verdade e valor enquanto uma e outra postura diante do divino ("que se distanciou" - "que não é") estão sob o signo de Dionísio. No pensamento de Sade a crueldade e a explicação de toda imaginável atividade sexual "colmatam o vazio deixado pela ausência de Deus" (como escreve Klossowski no prefácio para Aline et Valcour). Dizemos, de imediato, que não pretendemos estabelecer nenhum paralelo, necessariamente arbitrário e insensato, entre a débacle ${ }^{4}$ dos personagens

\footnotetext{
${ }^{4}$ Em francês, no original. Tradução: "ruína”. (n. t.)
} 
de Sade e as ações rituais dos devotos de Dionísio (tanto mais que a componente sexual do dionisismo é quase ausente - como sublinha Jeanmaire - no menadismo). Do mesmo modo, não queremos avaliar o "dionisismo" de Sade considerando análogas a ferocidade do deus evocado por Eurípides, nas Bacantes, e as dos heróis de Sade. A relação que nos propomos a colocar em evidência é menos óbvia e mais autêntica. De fato, Sade não pode ser dito devoto nem de Dionísio, nem de qualquer outro deus: para ele, "Deus" não existe; citamos no início a noite da "consciência infeliz" justamente para evitar reconhecer no comportamento dos personagens de Sade algum ato de devoção das divindades nomeadas ou silenciadas. Entretanto, existe para Sade um fundamental princípio de contradição - não personificado, presente na raiz do ser - que atribui à satisfação dos desejos de crueldade e de atividade sexuais livres de qualquer censura a característica de "perversões" e de "anomalias monstruosas", no mesmo instante em que Sade aí reconhece um comportamento universalmente ideal: o comportamento da idade de ouro. É provável que já se insistiu em demasia (mesmo para a influência dos estudos de psicologia sobre o assim chamado comportamento "sádico") na presumida necessidade de infringir uma lei social ou religiosa como condição essencial da plena satisfação dos personagens "perversos" ou "monstruosos" de Sade. Na realidade, bastaria pensar no significado profundo de símbolos como o castelo ou o monastério inacessíveis (onde se desenvolvem as "monstruosidades" evocadas por Sade) para entender que o princípio de contradição, ínsito no pensamento de Sade e no comportamento dos seus personagens, não é dirigido tanto contra as censuras da sociedade quanto contra à existência humana na sua inteireza. O castelo ou o monastério, isolados do resto do mundo, são os núcleos do mundo futuro: símbolos de fundação de uma futura idade de ouro, da qual se pode dizer apenas que nascerá da contradição sistemática do humano e da humanidade como espécie.

Nesse sentido, Sade é particularmente próximo ao dionisismo ou, de modo mais exato, sua experiência abre um caminho diverso ao "dionisismo" do tempo da "consciência infeliz". Mais do que evocar o contraste Dionísio/ Apolo, Sade sugere que a experiência do nada, se vivida na sua plenitude, possa conduzir para a forma graças à força que é ínsita no nada e que o impele ao ser. Além disso, ele reconhece em todo comportamento humano que tenha como perspectiva o sofrimento e a morte (enquanto consequência de assassinato ou atividade sexual estranha à conservação da espécie) um cami- 
nho para o nada. Um indício da autêntica posição de Sade nos confrontos com a "consciência infeliz" é constituído, aliás, pelo assim chamado aparato erudito de alguns dentre seus romances: pelas notas que justificam o comportamento dos personagens com a citação de institutos da antiguidade e, em geral, pelo horizonte de um passado em que os homens eram "mais livres" ou "mais razoáveis" (mais próximos do nada). É de novo o passado que, para sobreviver, deve ser esquecido e assim durar no presente. O presente em que vive Sade esqueceu o passado e Sade o deplora; mas a fatalidade desse esquecimento que aparece como uma degeneração (as proibições religiosas e sociais) permite a quem se isola do presente - no castelo ou no monastério - viver o passado e fundar o futuro. Desse ponto de vista, os símbolos dos "lugares inacessíveis", onde se cumprem "monstruosidades", permitem a Sade explicar quase de modo didático o processo esquecer/saber, quebrando a simultaneidade das duas experiências e isolando - uns no "mundo", outros no "castelo inacessível" - aqueles que esqueceram daqueles que sabem.

O elemento de contradição no comportamento dos personagens de Sade é, como a essência do dionisismo, o que, com sua presença única, impõe o pensamento do além. No entanto, o além de Sade não é um convencional reino ultraterreno, mas - em termos temporais - o além da espécie humana: a idade de outro ou a "forma" à qual exorta o Nada.

Se confrontamos tais proposições com o pensamento de Bachofen sobre a essência grega do dionisíaco, podemos observar que somente a preocupação histórica impediu Bachofen de lançar sua noção do reino de trevas, que pertence à matéria e, assim, também à vida, até o valor de pressuposto do comportamento "monstruoso" dos personagens de Sade. Segundo a interpretação de Bachofen, na experiência dionisíaca grega a vida pertence ao reino da morte - ao reino de Dionísio - , do qual ela brota continuamente apenas para garantir a multiplicidade dos mortos. Bachofen afirma, todavia, que Dionísio exige a "profusão vital" e que "Dem phallischen Gott der werdenden Welt ist das junge frische Leben am liebsten" ${ }^{5}$. Ele sublinha, além disso, até que ponto a lei que exige tal "profusão vital" quer também a morte, uma vez que morrer é pagar o próprio débito à matéria, e menciona a crueldade daqueles que estão sujeitos à força do deus: as mães que sacrificam os próprios

\footnotetext{
${ }^{5}$ Em alemão, no original. Tradução: "O deus fálico do mundo em gestação deseja a jovem e fresca vida." (n. t.)
} 
filhos, as bacantes ferozes.

Mais do que qualquer outro historiador, Bachofen insistiu em configurar Dionísio como "deus das mulheres", persuasor e sedutor do ânimo feminino. O princípio de vitalidade apaixonada é, para Bachofen, essencialmente feminino. Nesse ponto ele é distante do pensamento de Sade e sua oposição pode se configurar na antítese entre abandono entusiástico (feminino) à lei do nada e deliberada vontade (masculina) de aplicar a lei do nada. No quadro concebido por Bachofen, os heróis de Sade seriam criaturas "apolíneas", masculinas, convertidas ao dionisismo e convencidas a colocar ao serviço do deus das mulheres sua vontade masculina.

Essa antítese tem um significado profundo no âmbito do período da "consciência infeliz", uma vez que contrapõe abandono e vontade como normas de comportamento em relação com a ausência dos deuses. Abandono é, aliás, o comportamento fatal de quem, depois que os deuses "se distanciaram", evoca uma nova mitologia em que reconhece um novo Dionísio e um novo Apolo: criar um mito significa, se o mito é genuíno, abandonar-se ao fluxo do mito, deixá-lo expandir em si. A vontade, ao contrário, no sentido do comportamento volitivo dos personagens de Sade, que procura obedecer à lei do nada com a convicção de que nada "urja a uma forma" (à forma), exclui a criação de mitos: Creuzer e Bachofen foram genuinamente criadores de mitos (além de estudiosos de mitos), Sade não criou nenhum mito, mas foi obrigado a sofrer um mito: o mito do dever, que com menor exatidão se poderia também chamar mito do desejo, da libido etc., e que impõe a seus personagens o dever de explicar toda forma de crueldade e de atividade sexual estranha à conservação da espécie, de modo que os homens obedeçam sem reservas a lei do Nada.

5. A importância, no pensamento de Sade, da vontade como instrumento para adequar-se à lei do Nada induz espontaneamente a reconhecer na futura idade de ouro, ou na forma em que emerge o Nada, que está no horizonte dos personagens de Sade, um modo diverso daquele de Schopenhauer apenas enquanto projetado no futuro e ignoto. Excluindo o ignoto (ao menos nos limites garantidos pela faculdade profética), o mesmo discurso conduz, em uma etapa sucessiva, a Nietzsche. O mundo futuro é profetizado por Nietzsche em termos que Bachofen em partes teria aprovado, mas que, nas suas últimas conclusões, Bachofen por certo teria considerado sumariamente negativos. $\dot{E}$ evidente, com efeito, a angústia que proporcionaria ao patrício da Basileia 
uma profecia segundo a qual a dissolução social igualitária correspondente ao advento soberano de Dionísio teria sido a preparação do advento dos grandes guias, destinados a dominar as multidões de homens tornadas livres e iguais pela soberania do deus. No nosso discurso, todavia, o pensamento de Nietzsche e suas críticas ao de Schopenhauer são particularmente importantes como conclusões da experiência da "consciência infeliz", que também foi própria a Bachofen.

Retomando o adjetivo consagrado por Nietzsche, mas em sentido muito diverso, Jeanmaire conclui seu volume afirmando que "na história, por certo muito inatual, do dionisismo" a negação radical dos valores tradicionais, própria do cristianismo dos primeiros séculos e também voltada contra o culto de Dionísio, representa provavelmente um elemento de atualidade. Escrevendo assim, ele estabelece um paralelismo entre a função que reconhece peculiar ao dionisismo - a renovação de uma visão do universo e do destino - e aquela, por ele considerada análoga, do cristianismo. Esses grandes movimentos de renovação espiritual - sustenta Jeanmaire - são caracterizados sobretudo por uma violenta e iconoclasta destruição dos valores tradicionais (e apenas de modo secundário por uma renovação ideológica ou pela epifania de novos deuses). A história espiritual da humanidade é, portanto, escandida por movimentos de revolta e de destruição, que marcam o ritmo profundo da vida. Do dionisismo é assim inatual a ideologia e, antes, atual é o caráter destruidor e inovador.

A contraposição dos adjetivos "atual" e "inatual" nos conduz, além disso, ao núcleo do nosso discurso, isto é, ao significado e ao valor do tempo, seja no dionisismo originário, seja naquele nascido na noite da "consciência infeliz". Ao criticar o pensamento de Schopenhauer, Nietzsche de fato se preocupou de modo particular com o significado e a natureza do tempo. Se, para Schopenhauer, o passado existe enquanto intelecto movido pela vontade que the traça a forma, para Nietzsche é preciso considerar o "passado do intelecto", sua história, ou melhor, sua pré-história. Desse modo será possível penetrar a noite em que afunda o passado (ou a parte de passado) que não pode encontrar-se no pensamento presente, uma vez que o pensamento presente o considera causa do presente. Essa perspectiva antropológica e psicológica das relações entre passado e presente (que evidentemente encontra paralelos nas pesquisas de Darwin e de Spencer) conclui, em certo sentido, o período da "consciência infeliz", dado que tende a atribuir a tal período uma precisa cono- 
tação histórica, mais do que existencial. Se o paradoxo dionisíaco consiste na dolorosa consciência entre esquecer e saber, o pensamento de Schopenhauer pode ser considerado sua radicalização, ou melhor, sua formulação em nível rigorosamente intelectual e na perspectiva mais de uma filosofia do conhecimento do que de uma experiência religiosa. O presente contém o passado pois o intelecto presente, movido pela vontade, concebe a única realidade do passado, excluindo um passado jacente no passado. O período da "consciência infeliz" coincide, portanto, com uma condição existencial, da qual o desaparecimento dos deuses é formulação em termos mitológicos. Mas quando Nietzsche propõe descobrir o passado "esquecido" (inexistente, do ponto de vista do intelecto presente) no gradual nascimento do intelecto - no "passado do intelecto", seria possível dizer, se a realidade do intelecto não devesse ser considerada como globalidade, ainda sem descuidar de sua diferenciação interior - , ele configura a noite da "consciência infeliz" como um determinado período da história e o distanciar-se dos deuses como um momento de alternados ciclos das relações entre homem e divino. Nessa perspectiva, os nomes de Dionísio e de Apolo não são mais, como para Creuzer e para Bachofen, designações de novos rostos divinos, nascidos dentro de uma nova mitologia correspondente à percebida condição existencial, mas símbolos - não mitos - das alternadas direções da história e das metamorfoses da humanidade. De Bachofen, com efeito, Nietzsche extrai não o mito de Dionísio, mas a historicização do dionisismo como instante, repetido, das metamorfoses humanas, e leva tal esquema histórico a conclusões que (como já notamos), é provável, teriam horrorizado Bachofen.

Seria profundamente romântico, e com toda probabilidade arbitrário, afirmar que o deus, tornado por Nietzsche de fato "inatual" enquanto descido da esfera atemporal do mito àquela do tempo histórico, fosse vingado com sua arma costumeira: isto é, conduzindo à loucura o heterodoxo. O esquema desse discurso "romântico" foi entretanto usado - mas com diversos tons e diversos fins - por Thomas Mann, no Doktor Faustus: se substituímos a palavra "demônio" pelo nome de Dionísio, Adrian Leverkühn se revela um Nietzsche que entrou em contato com o deus, mas que dele usufruiu conduzindo-o para dentro do tempo histórico, e expiou com a loucura sua culpa. A culpa de Nietzsche (uma vez que assim é preciso dizer, mesmo sem querer falar de uma punição) consistiu em usufruir historicamente de Dionísio, em descer Dionísio para dentro da história presente e futura, em configurar o advento 
soberano de Dionísio como fase fatal da história humana, preparadora da vinda dos grandes guias, dos humanos soberanos das multidões. Não foi genuína mitologia, mas tecnicização de um mito: o esforço por concluir a noite da "consciência infeliz" determinou a contemplação dos demônios, mais do que o retorno dos deuses. 